\title{
Components of variance and inter-relation of important traits for maize (Zea mays) breeding
}

\section{Ivan Ricardo Carvalho', Maicon Nardino ${ }^{1}$, Gustavo Henrique Demari ${ }^{1}$, Alan Junior de Pelegrin ${ }^{1}$, Mauricio Ferrari ${ }^{1}$, Vinícius Jardel Szareski $^{1}$, Victoria Freitas de Oliveira ${ }^{1}$, Mauricio Horbach Barbosa $^{2}$, Velci Queiróz de Souza ${ }^{3}$, Antonio Costa de Oliveira ${ }^{1}$, Luciano Carlos da Maia ${ }^{1}$}

\author{
${ }^{1}$ UFPEL - Federal University of Pelotas, Capão do Leão, RS, Brazil \\ ${ }^{2}$ UFSM - Federal University of Santa Maria Campus de Frederico Westphalen, RS, Brazil \\ ${ }^{3}$ UNIPAMPA - Federal University of Pampa, Dom Pedrito, RS, Brazil
}

*Corresponding authors: carvalho.irc@gmail.com

\begin{abstract}
The increase of maize yield is possible by increasing either the cultivated area, use of best technologies and also more productive genotypes. So, the aim of this study was to estimate the variance components and genetic parameters (individual REML), phenotypic linear correlations, genetic, environmental and canonical for agronomically important traits in maize. The experiments were conducted in the growing seasons of 2013/2014 in four environment of Rio Grande do Sul, Brazil. The design used was a randomized block arranged in a factorial design, including 79 maize of hybrids (simple/narrow genetic base) $\times$ four cultivation environments, arranged in three replicates. The measured traits were plant height, insertion ear height, prolificacy, ear diameter, ear length, number of grain rows per ear, number of grain per row, stem diameter, stem mass, ear mass, grains weight per ear, hundred grains weight and grains yield. The estimates of the variance components and genetics parameters (REML) were made throught the MHPRVG method, obtaining the genotypic variance, the variance of genotype $\times$ environment interaction, residual variance, individual phenotypic variance, heritability with broad sense to the total phenotypic effects, heritability of the genotypes mean, accuracy for the selection of the genotypes, determination coefficient to the effects of genotype $\times$ environnment interaction, genotypic correlation between performance of the environment, coefficient of genotypic variation,coefficient of residual variation and a overall average. We created a linear phenotypic, genetics, environmental and a canonical correlation. The variance components and genetics parameters (REML) identified a contribuition of the genetic variation for genotype $\times$ environment interaction, and heritability in a broad sense for the ear diameter, number of grains row and stem diameter. Phenotypic, genetic and environment linear positive trends was presented between the prolificacy as ear diameter and the grains mass per ear with the grain yield. The three canonical pairs were significant with intergroup dependence, by which the grains yield favored by the plant height, insertion ear height, prolificacy, ear diameter and number of grains per row. The criteria established by this study can be used in quantitative genetics research and maize genetic improvement to increase grain yield.
\end{abstract}

Keywords: biometry, plant breeding, interrelationships.

Abreviations: PH_plant height, EH_insertion ear height, PRO_prolificacy, ED_ear diameter, EL_ear length, NRE_number of grain rows per ear, NGR_number of grains per row, SD_stem diameter, SM_stem mass, EM_ear mass, GWE_grains weight per ear, HGW_hundred grains weight, GY_grains yield, $\sigma^{2} \mathrm{G}_{-}$genotypic variance, $\sigma^{2} \mathrm{INT}$ - genotype $\mathrm{x}$ environment interaction variance, $\sigma^{2} \mathrm{E}$ residual variance, $\sigma^{2} \mathrm{P}$ _phenotypic individual variance, $\hat{\mathrm{h}}^{2} \mathrm{~g}$, heritability with broad sense to the total phenotypic effects, $\hat{\mathrm{h}}^{2} \mathrm{mg}$ heritability of the genotypes mean, $\check{\text { rgg }}$ _accuracy for the selection of the genotypes, C2INT_determination coefficient to the effects of genotype $\mathrm{x}$ environment interaction, r̆gloc_genotypic correlation between performance of the environment, CVg_coefficient of genotypic variation, CVe_coefficient of residual variation, OA_overall average, REML_Restricted Maximum Likelihood and MHPRVG_method of harmonic mean weighted by genotypic values.

\section{Introduction}

The maize (Zea mays) presented as one of the main cereal cultivated in Brazil, with production amount of 82.3 million tons of grains, and average productivy of 5.4 tons per ha ${ }^{-1}$ in 2015/2016 crop season (Conab, 2015). The importance of the maize is referred to its wide use, being a raw material for human diet, but also to supply the input of several production chains (Garcia et al., 2006). In this context, it is necessary to constantly keep up the production levels of maize, which can be reached by increasing the area sown, use of best management technologies and culrivation of more productive genotypes (Carvalho et al., 2014).
The grain yield is influenced by abiotic and biotic factors, intrinsic characteristics of the genotype, cultivation environment, and genotype $\times$ environment interaction ${ }_{(\mathrm{G} \times \mathrm{E})}$ (Costa et al., 2010). The maize breeding encouters interference of $\mathrm{G} \times \mathrm{E}$ interaction, such as the difficulty of finding the bests genotypes, phenotypic stability and adaptability, the nature of the interaction of simple or complex and a differential answer of the characters that determinate the potencial productive of the culture (Ribeiro and Almeida, 2011). Conversely, some researches have pointed out that the grains mass, the ear dimensions, grains number per plant (Lopes et al., 2007), the plant stature (De Souza et al., 2014), the prolificity (De Carvalho et al., 2001), 
the number of grains per ear rows (Balbinot et al., 2005) are determinant to increase the grains yield in maize.

Therefore, it is crucial to understand and quantify the genetics variation involved in the phenotypic expression, and the fraction of the effects of the interaction $\mathrm{G} \times \mathrm{E}$ from the genetics effects. In this way, evaluation of the variance components and the genetics parameters of agronomically important characteristics allows to reveals important information to the breeders, wich in the future will serve as a support to decide wich selection strategy can be proceded. The search for more reliable results is viable to apply methodology based in mix models. For more reliable results it is feasible to apply methodologies based on mixed models, taking into account the Restricted Maximum Likelihood (REML) which makes it possible to estimate the variance components and genetic parameters more accurately (Resende et al., 1996).

The linear correlation evidence a trend of association between two characters. The phenotypic coefficent is due to genetics and environmental effects. The genetics causes are linked to pleiotropy where one determinate gene affects simultaneously two or more characters (Falconer, 1987), and the genetic links assume unstable nature (Churata et al., 1996). The environment correlation is intended to indicate the direction of environmental effects on linear association for both characters (Falconer, 1987). However, due to big number of characters measured and the dificulty in the correct interpretation of theirs interrelations we need to employ analysis that show which groups of characters are determinants to the main yield components. In this context, the canonical correlations are important for the breeding (Cruz et al., 2012).

There is lack of information for estimatation of variance componentes and genetics parameters per mix models, linears and canonical correlations in simple hybrids maize cultivated in different environments in Rio Grande do Sul, Brazil. This work aimed to estimate the variance components and genetic parameters (REML), the phenotypic linear and canonical correlations, genetics and environmental effecs for the characters of agronomic interest in maize.

\section{Results and Discussion}

\section{Estimation of variance components and genetic parameters}

The variance components and genetics parameters (REML) were estimated for the 79 simple maize hybrids cultivated in four environments of Rio Grande do Sul, Brazil (Table 2). The phenotypic magnitude of the character is closely related to effects attributed to the environment and a fraction is resulted from genetics variation. Therefore, to establish a relationship between the phenotypic individual variance $\left(\sigma^{2}\right)$ and the genotypic variance $\left(\sigma_{\mathrm{G}}^{2}\right)$, there is possible evidence that the ear diameter (ED), number of grains rows per ear (NRE), stem diameter (SD), stem mass (SM), and thousand grains weight (TGW) are determinated per $31.2 \%, 32.2 \%$, $45.0 \%, 27.9 \%$ and $20.9 \%$ due to genetics effects, respectively. In contrast, a prolificacy (PRO) and ear mass (ME) presented big influence of the environment on phenotypic proportions. The major environmental factors influence the phenotypic variation of 25 hybrids maize cultivated in six environments. They revealed that the grain weight per ear $(4.2 \%)$ and the number of tassel branches $(30.9 \%)$ were the characters more influenced by the genetic effects (De Souza et al., 2015).

The largest relative contributions of the genotypic variation $\left(\sigma_{\mathrm{G}}^{2}\right)$ and genotype $\times$ environment interaction variation $\left(\sigma^{2}{ }_{I N T}\right)$ were verified for the $\operatorname{ED}(78.6 \%)$, NRE (92.9\%), and SD $(91.0 \%)$. However, the phenotypic individual variance $\left(\sigma_{P}^{2}\right)$ contributed in a superior way to the characters EH (78.1\%), EM (77.4\%), GWE (92.6\%) and to GY (66.0\%). The heritability revealed a fraction of genetic variance existing in the phenotypic variance and can indicate experimental reliability and precision for the phenotype (Ramalho et al., 2012). Furthermore, the heritability with broad sense for the total genotypic effects without the interference of genotype $\mathrm{x}$ environment interaction $\left(\hat{\mathrm{h}}_{\mathrm{g}}^{2}\right)$ reported higher magnitudes to the characters ED (0.31), NRE (0.32), SD (0.45), SM (0.27) and TGW (0.24). Similarly, the heritability of genotype average $\left(\hat{\mathrm{h}}^{2}{ }_{\mathrm{mg}}\right)$ was considered high for the characters ED (0.81), NRE (0.84) and SD (0.89).

The greatest accuracies provide high experimental precision, effectiveness of selection strategies and genetic gains to the characters ( $\mathrm{Da}$ Costa et al., 2000). High accuracies $\left(0.70<\check{r}_{g \breve{g}}\right)$ were obtained for the characters $\mathrm{PH}$, ED, EL, NRE, NGR, SD, MSM and TGW, moderate $\left(0.50<\check{\mathrm{r}}_{\mathrm{gg}}<0.65\right)$ for EH, EM and GY, and low $\left(0.10<\check{\mathrm{r}}_{\mathrm{gg}}<0.40\right)$ for PRO and GWE according to Resende and Duarte (2007). The determinated coefficient of the genotype $x$ environment interaction effects $\left(\mathrm{C}^{2}{ }_{\text {INT }}\right)$ indicated the participation of the interaction effects in total variation of traits, where the $\mathrm{PH}$ and $\mathrm{EH}$ presented the greatest intensity with 0.30 and 0.36 , respectively. The genotypic correlation between the environment performance $\left(\breve{\mathrm{r}}_{\mathrm{loc}}\right)$ presented higher $\left(0.70<\breve{\mathrm{r}}_{\mathrm{loc}}\right)$ for the characters ED $(0.78)$, NRE (0.92) and SD (0.90) and revealed the biggest participation of the interaction characterized as simple (Pupin et al., 2015). Low coefficients $\left(\breve{\mathrm{r}} \mathrm{g}_{\mathrm{loc}}<0.50\right)$ were expressed for PH $(0.30)$, EH (0.21), PRO (0.18), EM (0.22), GWE (0.07) and GY (0.33). For these characters a low genotypic correlation between the environments indicate greater interactions effects with complex nature and results in lower phenotypic stability of genotypes (Rosado et al., 2012).

The genotype variation coefficient $(\mathrm{CVg})$ presented higher magnitudes to the characters SM (14.54\%) and TGW $(8.11 \%)$ and indicates greater genetic variability of the simple maize hybrid for these characters. In contrast, the $\mathrm{PH}$ $(4.16 \%)$, PRO (3.69\%), ED (4.05\%) and the GWE (3.49\%) revealed smaller contributions to the genetic variation to phenotypic performance. The residual variation coefficient (CVe) presented above the GY $(29.25 \%)$ because this character was influenced by $9.53 \%$ through the genotype $\mathrm{x}$ environment interaction ( $\left.\sigma^{2} I N T\right)$, and $14.44 \%$ to residual effects $\left(\sigma^{2} E\right)$. The overall average of grains yield (GY) for the hybrid maize cultivated in the four producing regions at the Rio Grande do Sul was $8449.61 \mathrm{~kg} \mathrm{ha}^{-1}$ of grains. The average results reached $47.00 \%$ higher than the brazilian average $\left(4478.00 \mathrm{~kg} \mathrm{ha}^{-1}\right), 15.42 \%$ above the average $(7146.00 \mathrm{~kg} \mathrm{ha}$ ${ }^{1}$ ) of the south region of Brazil and $34.38 \%$ higher to the productivities obtained at the Rio Grande do Sul $(5544.00 \mathrm{~kg}$ $\mathrm{ha}^{-1}$ ) for the growing seasons 2013/2014 (Conab, 2015).

\section{Phenotypic, genetic and environmental correlation}

The estimates of linear correlation for the characters PH, EH, PRO, ED, EL, NRE, NGR, EM, GWE, TGW, GY, SD, and SM were measured in 79 hybrids of maize cultivated in four environment $(\mathrm{N}=948)$ at the Rio Grande do Sul, Brazil (Table 3). About 78 linear associations realized, where 56 phenotypic correlations $(r P)$ were significant by the $t$ test, 9 genotypic correlations $(\mathrm{rG})$ and 70 environmental correlations ( $\mathrm{rE}$ ) were significant with the bootstrap method at $5 \%$ of probability, where the coefficient of linear correlation followed the classification proposed per Carvalho 
et al. (2004). Overall, the genotypic associations featured significantly higher than the phenotypic. Our studies determined that these trends are from the increased contribution of genetic fraction and expression of character magnitude with smaller environmental effects (Churata et al., 1996).

The linear associations were significants for the PRO $\times \mathrm{ED}$ $\left(r_{P}=0.35 ; r_{G}=0.59 ; r_{E}=0.10\right)$ and GWE $\times \mathrm{GY}\left(r_{P}=0.70 ;\right.$ $\left.r_{G}=0.75 ; r_{E}=0.32\right)$. These results show that the positive genetic trend of the maize hybrid increase the number of the ears per plant along with ear diameter. Similarly, ears with higher grain mass are associated with more productive genotypes. For both of linear associations the environment influence was similar to the positive effects that increase the characters. When The coefficient of phenotypic correlation $\left(r_{P}\right)$ is less than the genetic $\left(r_{G}\right)$, it indicates that the phenotypic manifestation is controlled in a superior manner by genotypic effects and its interpretation can be used in the selection of strategies to have greater reliability and efficiency (De Gonzáles et al., 1994).

Phenotypic and genotypic trends were negative for the ED $\times \operatorname{NGR}\left(r_{P}=-0.22 ; r_{G}=-0.40 ; r_{E}=0.41\right)$ and NGR $\times \operatorname{SD}\left(r_{P}=-\right.$ $\left.0.44 ; r_{G}=-0.58 ; r_{E}=0.15\right)$. However, the environmental effects presented positive. Ears with smaller diameter genetically reduce the number of the grains contained in each ear row, and consequently result in stems with smaller diameter. For both associations, the environmental effects influenced with the same broad sense heritability values for these characters. However, when the broad sense of the genetics and environmental coefficients are opposite, it becomes indicative that genetic and environmental variation determined character distinctly (Falconer, 1987).

The negative genetics associations were observed for the characters EL $\times \mathrm{SD}\left(r_{G}=-0.26 ; r_{E}=0.31\right)$ and NGR $\times \mathrm{SM}$ $\left(r_{G}=-0.40 ; r_{E}=0.48\right)$. However, environmental effects were evidenced positively. Trends point that ears with superior longitudinal dimensions reduced the stem diameter. This association was proved the inverse relationship expressed through the grains number per ear row and the stem mass. The grains yield presented dependent to the agronomics character sets. In this context, the possible envidence was $\mathrm{PRO} \times \mathrm{GY} \quad\left(r_{G}=0.65 ; r_{E}=-0.16\right)$ that revealed genetic correlation high and positive. However, the environmental effects presented negative associations. When the genetical characteristics beneficially influenced this association, the environment penalized its effects.

Plant height $(\mathrm{PH})$ revealed positive phenotypic and environment trends with EH $\left(r_{P}=0.80 ; r_{E}=0.61\right)$, ED $\left(r_{P}=0.42 ; r_{E}=0.23\right), \mathrm{EM}\left(r_{P}=0.42 ; r_{E}=0.28\right), \operatorname{GWE}\left(r_{P}=0.42\right.$; $\left.r_{E}=0.24\right)$, TGW $\left(r_{P}=0.39 ; r_{E}=0.29\right)$, GY $\left(r_{P}=0.37 ; r_{E}=0.17\right)$, $\mathrm{SD}\left(r_{P}=0.23 ; r_{E}=0.07\right)$ and $\mathrm{SM}\left(r_{P}=0.32 ; r_{E}=0.26\right)$. The linear associations show that taller plants increase the ear height, and can change the arrangement of the spikes and the plant balance. In total, they can modify the dimensions and the ear mass positively to the grain yield. However, it can result in lodging and breakage of stalk in field conditions. Previous reports have defined that plant height in maize is dependent to the area and leaf archiecture, photosynthetic efficiency and hormonal balance (De Souza et al., 2015). It highly influenced by genotype $\times$ environment interaction, technological level of used genotype, and water availability (Carvalho et al., 2014).

The prolificacy (PRO) showed low and positive phenotypic association with $\mathrm{EM}\left(r_{P}=0.23 ; r_{E}=0.10\right), \mathrm{SD} \quad\left(r_{P}=0.25\right.$; $\left.r_{E}=0.07\right)$ and SM $\left(r_{P}=0.25 ; \quad r_{E}=0.08\right)$. However, environmental effects presented low and positive magnitudes for all the associations. The results indicate that the increase in the ears number per plant benefited the increase of ear mass. However, this may be due to bigger dimensions and the stem mass, which is characterized as assimilated drain to the plant.

The ear diameter (ED) presented phenotypic and environment correlation positive with $\mathrm{NRE}\left(r_{P}=0.55\right.$; $\left.r_{E}=0.40\right)$, EM $\left(r_{P}=0.71 ; r_{E}=0.68\right)$, GWE $\left(r_{P}=0.64 ; r_{E}=0.64\right)$, TGW $\left(r_{P}=0.61 ; r_{E}=0.52\right)$, GY $\left(r_{P}=0.57 ; r_{E}=0.24\right), \quad$ SD $\left(r_{P}=0.76 ; r_{E}=0.55\right)$ and SM $\left(r_{P}=0.59 ; r_{E}=0.59\right)$. Together, the ear lenght (EL) was associated with NRE $\left(r_{P}=0.46 ; r_{E}=0.64\right)$, EM $\left(r_{P}=0.46 ; r_{E}=0.66\right)$, GWE $\left(r_{P}=0.49 ; r_{E}=0.64\right)$, MMG $\left(r_{P}=0.33 ; r_{E}=0.41\right)$ and the GY $\left(r_{P}=0.28 ; r_{E}=0.21\right)$. The ear diameter and the ear lenght presented similar trends that resulted in ears with higher dimensions and mass. However, the magnitude of grain mass was incremented leading to the higher grain yield. The environmental effects were positive for all the associations, showing that these characters are phenotypically inherent. The ear lenght and the ear diameter are determinants for thousand grains weight and grains mass per ear. These characters can eb used for an indirect selection procedure to obtain maize genotypes with production (Lopes et al., 2007).

The number of grains row per ear (NRE) was negatively associated to NGR $\left(r_{P}=-0.27\right)$. In contrast, phenotipic and environmental positive trends were obtained for EM $\left(r_{P}\right.$ $\left.=0.26 ; r_{E}=0.24\right)$, GWE $\left(r_{P}=0.26 ; r_{E}=0.21\right), \mathrm{SD}\left(r_{P}=0.46 ; r_{E}\right.$ $=0.37)$ and $\mathrm{SM}\left(r_{P}=0.24 ; r_{E}=0.22\right)$. The number of grains per row (NGR) revealed positive phenotypic and environment trends with the GWE $\left(r_{P}=0.28 ; r_{E}=0.61\right)$. In contrast, the phenotypic coefficient was low and negative with TGW $\left(r_{P}=-0.26 ; \quad r_{E}=0.21\right)$ along with positive environmental effects for this association. The trends indicate that genotypes with more grain rows per ear can reduce the number of grain per row and individual mass of these grains but increase the grains mass of the ear. The grains number per ear, the dimensions and the grain mass, together with the prolificacy were essential to raise the maize productive potencial. However, the characters were significantly influenced by environmental effects (Agrama, 1996).

The ear mass (EM) revealed high and positive phenotypic trends with GWE $\left(r_{P}=0.91 ; r_{E}=0.84\right)$, TGW $\left(r_{P}=0.70 ; r_{E}\right.$ $=0.56)$ and the GY $\left(r_{P}=0.63 ; r_{E}=0.31\right)$. It was observed that for all associations there was a considerable fraction of positive environmental effects, influencing the relationships. Ears with superior mass resulted in the increase of grains mass per ear, which is beneficial to maize yield. The previous association studies on maize lines corroborates with our results, where we verified that the thousand grains weight and the total ear mass presented direct effect on grain yield and can be used as efficient selection strategies in a breeding program (De Souza et al., 2014).

\section{Canonical associations}

The multicollinarity diagnosis was carried out and a condition number of 78.09 was obtained, indicating this featured as weak. However, there was no problem with the matrix. The canonical correlation was set between the primary income characters (group I) matching a EM, GWE, TGW and GY, and the secondary characters (group II) such as PH, EH, PRO, ED, EL, NRE, NGR, SD and a SM. In contrast with the results obtained in canonical, three pairs were significant $(p<0.01)$ by the chi-square test (Table 4$)$. 
Table 1. Descriptions of the environment, geographic coordinates, altitude (m) and soil classification.

\begin{tabular}{llll}
\hline Cultivationenvironment & Geographiccoordinates & Altitude & Soilclassification* \\
\hline Campos Borges - RS & $28^{\circ} 55^{\prime} 36^{\prime \prime} \mathrm{S} / 53^{\circ} 01^{\prime} 40^{\prime \prime} \mathrm{O}$ & $513 \mathrm{~m}$ & Latosol darkred \\
Fortaleza dos Valos - RS & $28^{\circ} 47^{\prime} 50^{\prime \prime} \mathrm{S} / 53^{\circ} 133^{\prime} 22^{\prime} \mathrm{O}$ & $406 \mathrm{~m}$ & Latosol darkred \\
Santa Rosa - RS & $27^{\circ} 52^{\prime} 16^{\prime \prime} \mathrm{S} / 54^{\circ} 28^{\prime} 55^{\prime} \mathrm{O}$ & $268 \mathrm{~m}$ & Latosol red distroferric \\
Tenente Portela - RS & $27^{\circ} 23^{\prime} 31^{\prime \prime} \mathrm{S} / 53^{\circ} 46^{\prime} 50^{\prime \prime} \mathrm{O}$ & $420 \mathrm{~m}$ & Latosol red ferrictypical alumino \\
\hline
\end{tabular}

Table 2. Estimation of variance components and the genetic parameters (REML) for 79 hybrid of maize cultivated in four environments of Rio Grande do Sul, Brazil.

\begin{tabular}{|c|c|c|c|c|c|c|c|}
\hline \multirow{2}{*}{$\begin{array}{l}\text { Variancecomponents } \\
\text { REML }\end{array}$} & \multicolumn{7}{|c|}{ Characters $^{2}$} \\
\hline & PH & EH & PRO & ED & EL & NRE & NGR \\
\hline$\sigma^{2} G^{1}$ & 61.14 & 30.94 & 0.00 & 3.25 & 0.42 & 0.61 & 2.68 \\
\hline$\sigma^{2} I N T$ & 133.74 & 110.47 & 0.00 & 0.90 & 0.23 & 0.05 & 2.06 \\
\hline$\sigma^{2} E$ & 245.47 & 160.94 & 0.06 & 6.24 & 2.58 & 1.21 & 15.32 \\
\hline$\sigma^{2} P$ & 440.36 & 302.36 & 0.06 & 10.41 & 3.24 & 1.89 & 20.07 \\
\hline$\hat{h}^{2} g$ & 0.13 & 0.10 & 0.01 & 0.31 & 0.12 & 0.32 & 0.13 \\
\hline$\hat{h}^{2} m g$ & 0.53 & 0.42 & 0.17 & 0.81 & 0.60 & 0.84 & 0.60 \\
\hline$\check{r} g \check{g}$ & 0.72 & 0.65 & 0.41 & 0.90 & 0.77 & 0.91 & 0.77 \\
\hline$C^{2} I N T$ & 0.30 & 0.36 & 0.08 & 0.08 & 0.07 & 0.02 & 0.10 \\
\hline r̆gloc & 0.31 & 0.21 & 0.18 & 0.78 & 0.63 & 0.92 & 0.56 \\
\hline$C V g(\%)$ & 4.16 & 5.57 & 3.69 & 4.05 & 3.87 & 5.15 & 5.09 \\
\hline $\mathrm{CVe}(\%)$ & 8.35 & 12.71 & 24.74 & 5.61 & 9.59 & 7.22 & 12.16 \\
\hline$O A$ & 187.57 & 99.75 & 1.00 & 44.48 & 16.75 & 15.28 & 32.18 \\
\hline Variancecomponents & \multicolumn{7}{|c|}{ Characters $^{2}$} \\
\hline REML & SD & SM & EM & GWE & TGW & GY & \\
\hline$\sigma^{2} G^{1}$ & 2.80 & 8.79 & 63.96 & 172.81 & 466.08 & \multicolumn{2}{|c|}{350326.76} \\
\hline$\sigma^{2} I N T$ & 0.28 & 6.81 & 218.61 & 2149.20 & 423.97 & \multicolumn{2}{|c|}{680995.52} \\
\hline$\sigma^{2} E$ & 3.13 & 15.90 & 782.95 & 5752.16 & 1051.22 & \multicolumn{2}{|c|}{6109989.32} \\
\hline$\sigma^{2} F$ & 6.22 & 31.51 & 1065.52 & 8074.18 & 1941.28 & \multicolumn{2}{|c|}{7141311.61} \\
\hline$\hat{h}^{2} g$ & 0.45 & 0.27 & 0.06 & 0.02 & 0.24 & \multicolumn{2}{|c|}{0.04} \\
\hline$h^{2} m g$ & 0.89 & 0.74 & 0.34 & 0.14 & 0.70 & \multicolumn{2}{|l|}{0.34} \\
\hline$\check{r} g \check{g}$ & 0.94 & 0.86 & 0.58 & 0.38 & 0.84 & \multicolumn{2}{|l|}{0.58} \\
\hline$C^{2} I N T$ & 0.04 & 0.21 & 0.20 & 0.26 & 0.21 & \multicolumn{2}{|l|}{0.09} \\
\hline$\check{r}$ gloc & 0.90 & 0.56 & 0.22 & 0.07 & 0.52 & \multicolumn{2}{|l|}{0.33} \\
\hline$C V g(\%)$ & 6.53 & 14.54 & 5.51 & 3.49 & 8.11 & \multicolumn{2}{|l|}{7.00} \\
\hline $\mathrm{CVe}(\%)$ & 6.90 & 19.56 & 19.30 & 20.13 & 12.18 & \multicolumn{2}{|c|}{29.25} \\
\hline$O A$ & 25.64 & 20.38 & 144.93 & 376.58 & 266.07 & \multicolumn{2}{|c|}{8449.61} \\
\hline
\end{tabular}

Table 3. Estimate of phenotypic correlation $(r P)$ and genetic $(r G)$ and environmental $(r E)$ for the 79 hybrids of maize cultivated in four environment on the Rio Grande do Sul, Brazil.

\begin{tabular}{|c|c|c|c|c|c|c|c|c|c|c|c|c|c|c|}
\hline & & ${ }^{1} \mathrm{PH}$ & $\mathrm{EH}$ & PRO & ED & EL & NRE & NGR & EM & GM & TGM & GY & SD & SM \\
\hline \multirow{3}{*}{${ }^{1} \mathrm{PH}$} & $\mathrm{rP}$ & . & 0.80 ** & 0.16 & $0.42 * *$ & 0.16 & 0.14 & 0.08 & $0.42 * *$ & $0.42 * *$ & $0.39 * *$ & $0.37 * *$ & $0.23^{*}$ & $0.32 * *$ \\
\hline & $\mathrm{rG}$ & . & 0.87 & 0.29 & 0.47 & 0.17 & 0.18 & 0.06 & 0.5 & 0.55 & 0.42 & 0.5 & 0.27 & 0.34 \\
\hline & $\mathrm{rE}$ & & $0.61^{++}$ & 0.03 & $0.23^{++}$ & $0.13^{++}$ & 0.01 & $0.12^{++}$ & $0.28^{++}$ & $0.24^{++}$ & $0.29^{++}$ & $0.17^{++}$ & $0.07^{+}$ & $0.26^{++}$ \\
\hline \multirow{3}{*}{$\mathrm{EH}$} & $\mathrm{rP}$ & & . & 0.18 & $0.44 * *$ & 0.21 & 0.13 & 0.08 & $0.52 * *$ & $0.52 * *$ & $0.48 * *$ & $0.43 * *$ & $0.26^{*}$ & $0.38 * *$ \\
\hline & $\mathrm{rG}$ & & . & 0.27 & 0.49 & 0.21 & 0.16 & 0.03 & 0.63 & 0.68 & 0.52 & 0.58 & 0.29 & 0.4 \\
\hline & $\mathrm{rE}$ & & . & $0.12^{++}$ & $0.27^{++}$ & $0.21^{++}$ & 0.04 & $0.20^{++}$ & $0.33^{++}$ & $0.30^{++}$ & $0.34^{++}$ & $0.20^{++}$ & $0.13^{++}$ & $0.33^{++}$ \\
\hline \multirow{3}{*}{ PRO } & $\mathrm{rP}$ & & & . & $0.35 * *$ & -0.11 & $0.23 *$ & -0.06 & $0.23^{*}$ & 0.19 & 0.21 & 0.17 & $0.25^{*}$ & $0.25^{*}$ \\
\hline & $\mathrm{rG}$ & & & . & $0.59^{+}$ & -0.31 & 0.41 & -0.19 & 0.42 & 0.35 & 0.35 & $0.65^{++}$ & 0.42 & 0.43 \\
\hline & $\mathrm{rE}$ & & & . & $0.10^{++}$ & 0.06 & 0.02 & $0.06^{+}$ & $0.10^{++}$ & $0.09^{++}$ & $0.07^{+}$ & $-0.16^{++}$ & $0.07^{++}$ & $0.08^{++}$ \\
\hline \multirow{3}{*}{ ED } & $\mathrm{rP}$ & & & & . & -0.05 & $0.55 * *$ & $-0.22 *$ & $0.71 * *$ & $0.64 * *$ & $0.61 * *$ & $0.57 * *$ & $0.76^{* *}$ & $0.59 * *$ \\
\hline & $\mathrm{rG}$ & & & & . & -0.2 & 0.58 & $-0.40^{+}$ & 0.77 & 0.72 & 0.63 & 0.76 & 0.79 & 0.59 \\
\hline & $\mathrm{rE}$ & & & & & $0.45^{++}$ & $0.40^{++}$ & $0.41^{++}$ & $0.68^{++}$ & $0.64^{++}$ & $0.52^{++}$ & $0.24^{++}$ & $0.55^{++}$ & $0.59^{++}$ \\
\hline \multirow{3}{*}{ EL } & $\mathrm{rP}$ & & & & & 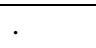 & -0.2 & $0.46^{* *}$ & $0.46 * *$ & $0.49 * *$ & $0.33 * *$ & $0.28 * *$ & -0.15 & 0.20 \\
\hline & $\mathrm{rG}$ & & & & & . & -0.3 & 0.38 & 0.34 & 0.4 & 0.31 & 0.34 & $-0.26^{+}$ & 0.08 \\
\hline & $\mathrm{rE}$ & & & & & . & $0.13^{++}$ & $0.64^{++}$ & $0.66^{++}$ & $0.64^{++}$ & $0.41^{++}$ & $0.21^{++}$ & $0.31^{++}$ & $0.64^{++}$ \\
\hline \multirow{3}{*}{ NRE } & $\mathrm{rP}$ & & & & & & 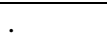 & $-0.27 *$ & $0.26^{*}$ & $0.26^{*}$ & -0.03 & 0.18 & $0.46^{* *}$ & $0.24 *$ \\
\hline & $\mathrm{rG}$ & & & & & & . & -0.36 & 0.29 & 0.31 & -0.04 & 0.24 & 0.47 & 0.24 \\
\hline & $\mathrm{rE}$ & & & & & & . & 0.06 & $0.24^{++}$ & $0.21^{++}$ & 0.00 & $0.09^{++}$ & $0.37^{++}$ & $0.22^{++}$ \\
\hline \multirow{2}{*}{ NGR } & $\mathrm{rP}$ & & & & & & & 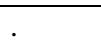 & 0.18 & $0.28 *$ & $-0.26^{*}$ & 0.08 & $-0.44 * *$ & -0.2 \\
\hline & $\mathrm{rG}$ & & & & & & & & $-0.07^{+}$ & 0.06 & -0.41 & -0.01 & $-0.58^{+}$ & $-0.40^{++}$ \\
\hline
\end{tabular}




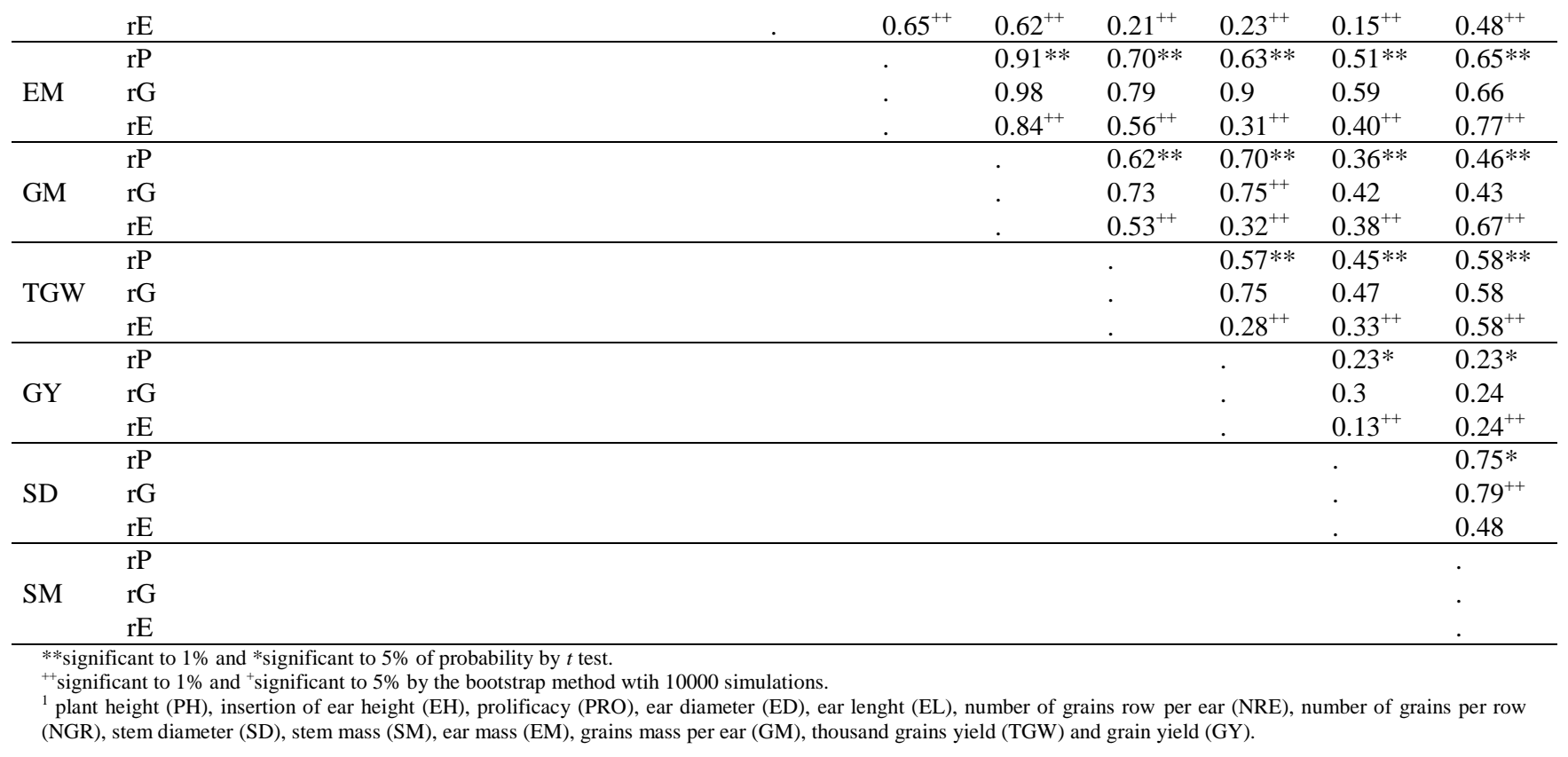

Table 4. Canonical loads for the primary yield characters (group I) and second characters (group II) in the canonical correlation (r) between groups, in 79 hybrid of maize cultivated in four environments on the Rio Grande do Sul, Brazil.

\begin{tabular}{llll}
\hline Group I & \multicolumn{3}{c}{ Canonical pairs } \\
\cline { 2 - 4 } Characters & $1^{\circ}$ & $2^{\circ}$ & $3^{\circ}$ \\
\hline EM $^{1}$ & 0.95 & 0.18 & 0.23 \\
GWE & 0.90 & 0.37 & -0.12 \\
TGW & 0.74 & -0.56 & 0.06 \\
GY & 0.70 & -0.13 & -0.67 \\
\hline Grupo II & & & -0.15 \\
\hline PH & 0.53 & -0.03 & -0.11 \\
EH & 0.65 & -0.02 & -0.38 \\
PRO & 0.10 & -0.38 & -0.16 \\
ED & 0.79 & 0.03 & 0.02 \\
EL & 0.55 & 0.30 & -0.06 \\
NRE & 0.30 & 0.45 & -0.16 \\
NGR & 0.13 & 0.79 & 0.23 \\
SD & 0.60 & -0.10 & 0.45 \\
SM & 0.78 & -0.06 & 0.58 \\
\hline R & 0.83 & 0.75 & $<0.01$ \\
P & $<0.01$ & $<0.01$ & 0.01 \\
\hline
\end{tabular}

p probability ${ }^{1}$ (group I) ear mass (EM), grains weight per ear (GWE), thousand grains weight (TGW) and grains yield (GY),(group II) plant height (PH), Insertion ear height $(\mathrm{EH})$, prolificacy $(\mathrm{PRO})$, ear diameter (ED), ear lenght (EL), number of grains rows per ear (NRE), number of grains per row (NGR), stem diameter (SD), stem mass (SM).

The first canonical pair revealed correlation of $r=0.83$ between groups. When the coefficient of intergroup correlation is high it shows high dependence between the character groups (Carvalho et al., 2015). The canonical interrelationships define the incremente of the ear mass and the granis mass per ear (group I). They were favored through the plant height, insertion ear height, prolificacy, ear diameter and lenght, number of grains rows per ear, stem diameter and mass (group II).

The maize genotypes with taller plants may show higher competitive ability. This enables light intercept more efficiently and photosynthetically active energy, due to more leaf area. However, they can meet the need of assimilates to form and maintain more ears per plant, and even cause larger dimensions. These associations have been proven in research conducted with maize hybrids grown in six environments, where ear grain mass and grain yield were increased by taller plants and leaf area (De Souza et al., 2015).

The second canonical pair revealed intergroup correlation of $r=0.75$. The smaller thousand grains weight (group I) was obtained in ears with higher lenght, number of grains row per ear and number of grains per row. However, they were observed in less prolific plants and smaller diameter stem. The canonical trends are justified when the ears reveal higher dimensions, when has been properly fertilized. Before that, the number of grains per ear increases and modifies the arrangement of the ear grains and reduces the space available for the expansion of each grain.,Therefore, plants with less number of the ears can direct their assimilated to less drains, forming more but lighter grains per ear. The maize productive potencial is dynamically dependent to the architecture and leaf area, photosynthesis, pollination and efficient eggs fertilization, number of grains per ear formed, 
accumulation and expansion of carbohydrates in the endosperm, and grain size (Magalhães and Durães, 2006).

The third canonical pair presented intergroup correlation of $\mathrm{r}=0.58$, where the emphasis is assigned to the grain yield (group I), whereas unfavorable to the increase of diameter and the stem mass. However, it is determinated through the plant height, insertion ear height, prolificacy, ear diameter and number of grains per ear row (group II). In the conditions of this study, superior productive potential genotypes were obtained with greater height, prolific and ear diameter which was proportionally inversed to the stem diameter, providing increased in the depth of the grain. The path analysis of grains yield as dependent trait showed that this character was determinated through the grains mass and the ear diamensions (Lopes et al., 2007), prolificacy (Carvalho et al., 2001), and insertion ear height (De Souza et al., 2014).

Before identification of contribution of the variance components (REML) evidence the genetic fraction of phenotype expression and before knowing the weight of genetic parameters by genotype $\times$ environment interaction, joint list with linear phenotypic, genetics and environmental association are pronounceable among the favourable characters. Also, canonical interrelations were established for the primary yield characters (group I) and the second characters (group II). It can be considered to compose future selection strategies on a maize breeding program to obtain superior genotypes in grain yields.

\section{Materials and Methods}

\section{Characterization of experimental conditions}

The experiments were conducted in the growing seasons 2013/2014 in four agricultural regions in Rio Grande do Sul, Brazil. The climate for all environments was characterized per Köppen with $C f a$ subtropical. The informations related to the cultivation environment are shown in Table1.

\section{Experimental design}

A randomized block arranged in a factorial design was used, in which 79 maize of hybrids (simple/narrow genetic base) $\times$ four cultivation environments assigned in three replicates. The genotypes used in this study are shown in Supplementary Table $1 \mathrm{a}$ and $1 \mathrm{~b}$.

The experiments were based on direct seeding system, which carried out in the second fortnight of setember of 2013. The basic fertilizer of $400 \mathrm{~kg} \mathrm{ha}^{-1}$ NPK $(10-20-20)$ used was, in which $135 \mathrm{~kg} \mathrm{ha}^{-1}$ of nitrogenin applied in $\mathrm{V}_{4}$ and $\mathrm{V}_{6}$ growth stages (Fancelli and Dourado Neto, 2000). The population density was 80000 plants per hectare. The experimental unit was four spaced lines $(0.5$ meters between rows) and five meters of length. The weed and insect pest control were done preventively to minimize the biotic effects on results of the experiments.

The characters of interest were measured in the useful area of each experimental unit wich was composed of two centerlines, where 0.5 meters from end of each line was discarded. The characters measured followed to the methodology proposed by Carvalho et al. (2014), and De Souza et al. (2015), such as plant height $(\mathrm{PH})$ in centimeters $(\mathrm{cm})$, insertion ear height $(\mathrm{EH})$ in $\mathrm{cm}$, prolificacy $(\mathrm{PRO})$ in units, ear diameter (ED) in milimeters (mm), ear lenght (EL) in $\mathrm{cm}$, number of grain rows per ear (NRE), number of grians per row (NGR), stem diameter (SD) in mm, stem mass (SM) in grams $(\mathrm{g})$, ear mass $(\mathrm{EM})$ in $\mathrm{g}$, grains weight per ear (GWE) in $\mathrm{g}$, hundred grains weight $(\mathrm{HGW})$ in $\mathrm{g}$, grains yield
(GY) in $\mathrm{kg} \mathrm{ha}^{-1}$.

The datas obtained was submitted to variance of analysis at $5 \%$ of probability to verify the assumptions, subject to the normality test of Shapiro Wilk (1965), and variance homogeneity of Bartlett's test (Steel et al., 1997). Posteriorly, affected up the estimates of the variance components and genetics parameters (REML) through the MHPRVG method, using the 54 model (Resende, 2007), it was followed the statistical $y=X r+Z g+W i+e$ where $y_{-}$is the data vector, $r_{-}$are the repetitions effects (fixed), $g_{-}$are the genotypic effects (random), $i_{-}$are the genotype $\mathrm{x}$ environment interaction effects (random), $e_{-}$are the residue (random). Estimates that, genotypic variance $\left(\sigma^{2} G\right)$, genotype $\times$ environment interaction variance $\left(\sigma^{2} I N T\right)$, residual variance $\left(\sigma^{2} E\right)$, phenotypic individual variance $\left(\sigma^{2} P\right)$, heritability with broad sense to the total phenotypic effects $\left(\hat{h}^{2} g\right)$, heritability fo the genotypes mean $\left(\hat{h}^{2} m g\right)$, accuracy for the selection of the genotypes $(\check{r} g \check{g})$,determination coefficient to the effects of genotype $\times$ environnment interaction $\left(C^{2} I N T\right)$, genotypic correlation between performance of the environment ( $\check{r}$ gloc), coefficient of genotypic variation $(\mathrm{CVg})$, coefficient of residual variation $(\mathrm{CVe})$ and a overall average $(\mathrm{OA})$.

A joint analysis of data was conducted, where all the characters were subjected to a linear phenotypic correlation, and the significance was obtained with $t$ test at 1 and $5 \%$ of probability (Steel et al., 1997). Similarly, the genetics and enviornmental correlation was obtained based on bootstrap method, through of 10 thousand simulations, totalizing $(N)$ 948 observations. The phenotypic matrix was submitted to multicolinearity diagnosis through the number of conditions $(N C)$ of matrix (Cruz et al., 2012). Subdivided in primary yield characters (group I) these were EA, GWE, TGW and GY, and secondary characters (group II) which evaluate PH, EH, PRO, ED, EL, NRE, NGR, SD and a SM. The canonical correlation analysis was preceded, whern the significance between the groups of characters was obtained $\mathrm{x}^{2}$ test (Cruz et al., 2012). The statistical analysis was conducted through the GENES software (Cruz, 2013).

\section{Conclusion}

The variance components and genetics parameters (individual REML) identified a contribuition of the genetic variation on the genotype $\times$ environment interaction, and heritability in a broad sense for the ear diameter, number of grains row and stem diameter. Phenotypic, genetic and environment linear positive trends were presented between the prolificacy as ear diameter and the grains mass per ear with the grain yield. The three canonical pairs were significant with intergroup dependence, in which the grains field favored the plant height, insertion ear height, prolificacy, ear diameter and number of grains per row. The criteria established by this study can be used in quantitative genetics research and maize genetic improvement to increase grain yield.

\section{Acknowledgments}

The authors thank capes, CNPq and FAPERGS for their financial support.

\section{References}

Agrama HA (1996) Sequential path analysis of grain yield and its components in maize. Plant Breeding. 115_343346.

Balbinot JRA, BackesR, Alves A, Ogliari J, Fonseca J (2005) Contribuição de componentes de rendimento na 
produtividade de grãos em variedades de polinização aberta de milho. C Agric Sci Technol. 11_161-166.

Carvalho FD, Lorencetti C, Benin G (2004) Estimativas e implicações da correlação no melhoramento vegetal. Universitária da UFPel, Pelotas, 142p.

Carvalho IR, De Souza VQ, Follmann DN, Nardino M, Schmidt D (2014) Desempenho agronômico de híbridos de milho em ambiente irrigado e sequeiro. E Biosfera. 10_ 1144-1145.

Carvalho IR, De Souza VQ, Nardino M, Follmann DN, Schmidt D, Baretta D (2015) Correlações canônicas entre caracteres morfológicos e componentes de produção em trigo de duplo propósito. Pesq Agrop Bras. 50(8)_690-697.

Churata BG, Ayla-Osuna JT (1996) Correlações genotípica, fenotípica e de ambiente e análise de trilha em caracteres avaliados no composto de milho (Zea mays) arquitetura. Ceres. 43_628-636.

CONAB (2015) Companhia nacional de abastecimento, acompanhamento da safra brasileira de grãos. 2_ 1-109.

Costa NFE, De Souza CJ, Lima JL, Cardoso AG (2010) Interação entre genótipos e ambientes em diferentes tipos de híbridos de milho. Pesq Agrop Bras. 45_1433-1440.

Cruz CD (2013) GENES a software package for analysis in experimental statistics and quantitative genetics. A Scientia Agron. 35 271-276.

Cruz CD, Regazzi AJ, Carneiro PCS (2012) Modelos biométricos aplicados ao melhoramento genético. Viçosa, Ed. da UFV, 514p.

Da Costa RB, Resende MD, De Araújo AJ (2000) Seleção combinada univariada e multivariada aplicada ao melhoramento genético da seringueira. Pesq Agrop Bras. 35_381-388.

De Carvalho CG, Borsato R, Cruz CD, Viana JM (2001) Path analysis under multicollinearity in S0 x S0 maize hybrids. Crop Breed Appl Biotec. 3_263-270.

De González PA, Lemos MA, Neto CER, Dos Reis OV, Tabosa JN, Tavares JJ (1994) Correlações genéticas, fenotípicas e ambientais em dois ciclos de seleção no milho dentado composto. Pesq Agrop Bras. 29_419-425.

De Souza TV, Ribeiro CM, Scalon JD, Guedes FL (2014) Relações entre componentes de rendimento e características morfológicas de milho. Magistra. 26_495-506.

De Souza VQ, Baretta D, Nardino M, Carvalho IR, Follmann DN, Konflanz VA, Schmidt D (2015) Variance componentes and association between maize hybrids morpho-agronomic characters. Científica. 43_246-253.

De Souza VQ, Carvalho IR, Follmann DN, Nardino M, Bellé R, Baretta D, Schmidt D (2015) Desfolhamento artificial e seus efeitos nos caracteres morfológicos e produtivos em híbridos de milho. R. Bras. de milho e sorgo. 14_61-74.

Falconer DS (1987) Introdução à genética quantitativa. UFV, 350p.

Fancelli AL, Dourado Neto D (2000) Produção de Milho. Ed. Agropecuária, Guaíba, 250p.

Garcia JC, Mattoso MJ, Duarte JD, Cruz JC (2006) Aspectos econômicos da produção e utilização do milho. Embrapa Milho e Sorgo. Circular Técnica, 25p.

Lopes SJ, Lúcio ADC, Storck L, Damo HP, Brum B, Dos Santos VJ (2007) Relações de causa e efeito em espigas de milho relacionadas aos tipos de híbridos. Ciência Rural. 37 1536-1542.

Magalhães PC, Durães FO (2006) Fisiologia da produção de milho. Embrapa Milho e Sorgo. Circular Técnica. 25p.

Pupin S, Dos Santos AVDA, Zaruma DUG, Miranda AC, Da Silva PHM, Marino CL, Sebbenn ML, De Moraes MLT (2015) Produtividade, estabilidade e adaptabilidade em progênies de polinização aberta de Eucalyptusurophylla ST Blake Scie Forest. 43_127-134.

Ramalho MAP, Abreu AFB, Santos JB, Nunes JAR (2012) Aplicações da genética quantitativa no melhoramento de plantas autógamas. Lavras, UFLA, 350p.

Resende MDV, Duarte JB (2007) Precisão e controle de qualidade em experimentos de avaliação de cultivares. Pesq Agrop Trop. 37_182-194.

Ribeiro JK, Almeida MIM (2011) Estratificação ambiental pela análise da interação genótipo $\mathrm{x}$ ambiente em milho. Pesq Agrop Bras. 46_ 875-883.

Resende MD, Prates DF, Jesus A, Yamada CK (1996) Estimação de componentes de variância e predição de valores genéticos pelo método da máxima verossimilhança restrita (REML) e melhor predição linear não viciada (BLUP) em Pinus. Boletim de Pesquisa Florestal. 32_ 1845.

Resende MDV. (2007) Software Selegem - REML/BLUP_ Sistema estatístico e seleção genética computadorizada via modelos lineares mistos. Colombo_ Embrapa Florestas, $150 \mathrm{p}$.

Rosado AM, Rosado TB, Alves AA, Laviola BG, Bhering LL (2012) Seleção simultânea de clones de eucalipto de acordo com produtividade, estabilidade e adaptabilidade. Pesq Agrop Bras. 47_964-971.

Shapiro SS, Wilk MB (1965) An Analysis of Variance Test for Normality (Complete Samples). Biometrika. 52_ 591611.

Steel RGD, Torrie JH, Dickey DA (1997) Principles and procedures of statistics_ a biometrical approach. New York, McGraw Hill Book, 250p. 